\title{
CHALLENGES OF EQUALIZATION OF EDUCATIONAL OPPORTUNITIES IN FEDERAL UNIVERSITIES IN SOUTH, SOUTH NIGERIA
}

\author{
Dr. Ameh Eyiene, Dr. Ekaette Samuel Okpon \\ Department of Educational Administration and Planning \\ Faculty of Education \\ University of Calabar, Calabar
}

\begin{abstract}
This study investigated the challenges of equalization of educational opportunities in federal universities in south south, Nigeria. One research question was raised and answered in the study. Descriptive research design was adopted. The population of this study was 52 Deans and 347 Heads of Departments, in four Federal Universities in the study area, summing up to a population of 399. Accidental sampling technique was utilized to get the sample of the study. The sample size of the study was 300 respondents. An instrument titled "Equalization of Educational Opportunities Scale (EEOS)" was used for data collection. Data collected were analyzed using Mean $(\bar{X})$. The criterion mean scores was 2.5 . Any mean score more than 2.5 was accepted, while the mean score of 2.5 and below was rejected. The results of the analysis revealed that there are challenges inhibiting equalization of educational opportunities in universities in Nigeria. It was concluded that for a meaningful university education and for Nigerian universities to achieve the goals for which they have been established, it is imperative for them to enjoy the principles of autonomy in order to enhance equal educational opportunities for all. Based on the findings, it was recommended that the need for the government to expand and improve the existing university facilities so as to be able to create more admission space for qualified candidates, increase the carrying capacities of universities and allow the universities to select their students.
\end{abstract}

Key words: Equalization, University, Opportunities, Autonomy.

\section{INTRODUCTION}

Access to university education in Nigeria has become a serious issue due to the sector's inability to provide an equal access to students that result in lowering the rate of student enrolment in higher education. This could be due to the fact that Nigerian adult population attaches much premium to university education and see education as the basic instrument for economic growth and technological advancement in any society. Most people in south south zone of Nigeria who demand for university education show desperation in their efforts to gain admissions into the highly limited available spaces.

It is in recognition of this fact that Nigerian government commits immense resources to ensure the provision of education for their citizens, and also tailor their policies toward ensuring that it is made accessible to the generality of their citizenry at all levels. The idea of equal opportunity with reference to education means equal rights for all irrespective of any circumstances by way of birth, race, sex, tribe, and disability. As stated in the National Policy on Education (2004), the Nigerian's philosophy of education is based on the integration of every individual into a sound, worthwhile, and equal educational opportunities for all citizens of the nation at the primary, secondary and tertiary levels. The philosophical assumption underpinning the policy is for every Nigerian child to have full access to quality education at all levels. Furthermore, the 1999 constitution of the Federal Republic of Nigeria lends credence to the above stating that government policy shall be directed towards achieving equal educational opportunities at all levels. Unfortunately, the right to 


\section{International Journal of Engineering Applied Sciences and Technology, 2019 \\ Vol. 4, Issue 3, ISSN No. 2455-2143, Pages 68-74 \\ Published Online July 2019 in IJEAST (http://www.ijeast.com)}

education and thus equal opportunity to education as a national objective for development has not been achieved (Okorie, 2014).

Equal educational opportunity refers to the availability of places for students in the educational systems, the social institution support for attendance and economic ability of individuals to pursue their education (Nwamuo, Okunamiri \& Okunamiri, 2015). Musa in Njoku, Ifediatu and Amadi (2015) stated that equal educational opportunities means equal access to formal education. This equality is regardless of differences in location, sex, social standing, ethnicity and even religion.

According to Musa (2011), succeeding Nigerian governments have taken lots of measures to ensure equality in the educational system. Firstly, they created a principal avenue of federal character where every tribe must be captured. The aim of this is to bring parity and equal opportunities as a means of achieving unity. The establishment of basic studies in educationally disadvantaged states, establishment of JAMB in 1977 to control admission and ensure quota irrespective of performance, introduction of predegree and remedial programmes through which candidates who were unable to pass the requisite exams for admission into higher education could gain admission after one year programme.

Similarly, there seems to be a political will to tackle the nation's long-festering difficulties in education most especially at the university level since the advent of democratically elected government. Among the government's notable policy reforms are institutional audits of all universities and associated parastatal bodies, revocation of the vice-chancellors' privilege of personally selecting 10 percent of each years' student intake, reconstitution of all university governing councils with broader representation, the licensing of more private universities, establishment of more federal universities and the reintroduction of the National Open University (by the former president of Nigeria, Chief Olusegun Obasanjo). The establishment of more universities by state governments is also complementing the effort of the Federal Government in this respect, among others.

Crowning these efforts was a new government policy on autonomy for universities announced on July 21, 2000 (Federal Ministry of Education, 2000). This policy gives university councils full responsibility for institutional governance (including the appointment of senior officers); restores block grant funding to universities; circumscribes the powers of the National Universities Commission; vests university senates with the authority to decide on curricula; return to universities the right to set admission criteria and select students; and lay the groundwork for new minimum academic standards.

Equally, commendable is government's effort to ensure quality higher education as well as equitable representation of all states in the tertiary education in Nigeria, which led to the creation of an agency called Joint Admission and Matriculation Board (by the military Decree No. 2 of 1978). One of the objectives of this agency is to develop machinery for stream lining tertiary admissions on a uniform and fair basis. In other words, the essence of setting up Joint Admission and Matriculation Board is to evolve uniform standards for tertiary admission and to ensure that merit serves as the basis of selection of candidates for admission. Unfortunately however, there has been a contradiction between the stated goals of Joint Admission and Matriculation Board and what is in practice (Obilade in Omebe \& Omebe, 2014).

Thus, Obilade in Omebe and Omebe (2014) observed that Joint Admission and Matriculation Board examinations are a mere political tool used by government to equalize educational opportunities between the advantaged states and disadvantaged states. Ukertor (2010:35) stated that the board's pattern of admission requires merit $45 \%$, catchment's area $35 \%$, and educational less developed states $20 \%$. Unfortunately, the entire tertiary education system in Nigeria can only admit about $15 \%$ of those seeking admission. The foregoing situations resulted in competition for access to the limited places and thereby led to sharp "practices such as cheating in examination, bribery for admission and manipulation of examination scores" (Ukertor, 2010:33).

In the same vein, the system of admission through Joint Admission and Matriculation Board had, thus, continued to come under heavy criticisms and there seem to exist a lack of relationship between Joint Admission and Matriculation Board entry scores and performance in degree examination. Akpotu (2005) stated that the major obstacles to increased access to higher education in Nigeria are the reform policies of quota system, catchment's area admission policy, poor and inadequate facilities as well as the limited absorptive capacity of Nigerian tertiary institutions.

Despite the successes recorded by government policies in widening the opportunity of quality education through the licensing of private universities, establishment of more federal universities and the reintroduction of the National Open University, there seems to exist inequality in educational opportunities in Nigeria in general and 


\section{International Journal of Engineering Applied Sciences and Technology, 2019 \\ Vol. 4, Issue 3, ISSN No. 2455-2143, Pages 68-74 \\ Published Online July 2019 in IJEAST (http://www.ijeast.com)}

South South zone in particular. It is based on this background that this study sought to assess the challenges of equalization of educational opportunities in Federal Universities in South South, Nigeria.

\section{STATEMENT OF THE PROBLEM}

In spite of the Federal government's efforts in making university education accessible, it is observed that, such efforts seems to have proved abortive. There are lots of cry from candidates who are qualified by Joint Admissions and Matriculation Board (JAMB) stipulated pass mark but cannot get admission into any programme in the university.

Reports by the Joint Admissions and Matriculation Board (JAMB), which conducts the selection examinations into higher institutions in Nigeria, showed that the nation is still unable to meet the social demands for universities. JAMB reported that 78,913 (representing 16.36 percent) of the 482,445 candidates in south south zone of Nigeria who wrote the examinations in the 2014/2015 academic session got admissions into universities. This could be due to many reasons which include but not limited to inadequate number of staff, accreditation challenges, acute shortage of infrastructural facilities, quota system policy, limited absorptive capacity (expressed in carrying capacity), poor government funding of education, poor attitude of government towards education, poverty among parents, socio-economic inequalities, birth order in the family, gender discrimination, individual differences among students, and ordinary level requirement deficiency. All these seems to hinder the equalization of university education opportunities.

Several attempts had been made by government to enhance equalization of educational opportunities. Such attempts were the establishment of National Open University System, creation of state universities, universities of agriculture and technology, government grants, bursary and scholarships, remedial studies, the cancellation of university discretion for admission and the licensing of private universities to cater for the educational need of the people aspiring for university education. Yet, inequality seems to still exist in educational opportunities in South South, Nigeria. It is based on these that this study seek to provide answers to the question: "What are the challenges of equalization of educational opportunities in Federal universities in South South, Nigeria?"

\section{RESEARCH QUESTION}

What are the mean ratings of the challenges of equalization of educational opportunities in federal universities in South South, Nigeria?

\section{METHODOLOGY}

The study adopted a descriptive design method. A descriptive design seeks to collect information from the members of the study population based on the variable under investigation. Descriptive design would enable us to examine what the perception of respondents in respect to the study. The population of this study was 52 Deans and 347 Heads of Departments, in four Federal Universities in the study area, summing up to a population of 399 . Accidental sampling technique was utilized to get the sample of the study. The sample size of the study was 300 respondents. An instrument titled "Equalization of Educational Opportunities Scale (EEOS)" was used for data collection. Data collected were analyzed using Mean $(\bar{X})$. The mean scores determine the acceptance or rejection of the rating items. In order to make decisions from results obtained, the mean responses were computed thus: $4+3+2+1=10 / 4=2.5$. In the light of the above computation, any mean score more than 2.5 was accepted, while the mean score of 2.5 and below was taken as rejected.

Results

What are the mean ratings of the challenges of equalization of educational opportunities in federal universities in South South, Nigeria?

Table 1

Mean $(\bar{X})$ ratings of the challenges of equalization of educational opportunities in federal universities.

\begin{tabular}{clcc}
\hline S/No. & \multicolumn{1}{c}{ Items } & $\bar{X}$ & SD \\
\hline 1 & Individual difference of students & 2.65 & 0.31 \\
2 & Socio-economic factors & 2.68 & 0.33 \\
3 & Birth position & 2.72 & 0.30
\end{tabular}


International Journal of Engineering Applied Sciences and Technology, 2019

Vol. 4, Issue 3, ISSN No. 2455-2143, Pages 68-74

Published Online July 2019 in IJEAST (http://www.ijeast.com)

\begin{tabular}{clrr}
4 & Parental literacy level & 3.00 & 0.22 \\
5 & Poor university autonomy in selection of students & 3.80 & 0.37 \\
6 & High cost of education & 2.40 & 0.24 \\
7 & Limited carrying capacity & 3.50 & 0.36 \\
8 & Poor government funding & 2.60 & 0.30 \\
9 & Inadequate teaching staff & 2.58 & 0.32 \\
10 & Accreditation issues & 3.01 & 0.34 \\
11 & Poor infrastructure in schools & 2.56 & 0.26 \\
\hline & Grand mean & $\mathbf{2 . 8 6}$ & \\
\hline
\end{tabular}

Table 1 revealed the mean ratings of the challenges of equalization of educational opportunities with high mean scores on items numbers 1(2.65), 2(2.68), 3(2.72), 4(3.00), 5(3.80), 7(3.50), 8(2.60), 9(2.58), 10(3.01) and 11(2.56). Item number 6(2.40) had a low mean score. From the result presented, it can be observed that all the items were highly rated by the respondents except item 6 which had a mean of 2.40 less than the criterion mean of 2.50 . However, with the grand mean of 2.86 , the result indicates that the respondents are of the opinion that there are challenges inhibiting equalization of educational opportunities in federal universities in south south, Nigeria.

\section{DISCUSSION}

The results revealed that there are challenges facing equalization of educational opportunities in federal universities in south south, Nigeria. This result corroborates the findings of Ngwuogu, Iloka, Ameh and Deeka-Menegbon (2015) who opined that our educational system does not take cognizance of the ability and aptitude of the individual students enrolled into our educational institutions. They added that abolishing fees, providing common curricula, equipping schools with adequate instructional materials are not enough criteria for meeting educational needs of every child in a given society. Subjecting both the mentally retarded and the normal child to the same curriculum is a barrier rather than creating equality of educational opportunity.

Socio-economic inequalities are common phenomenon in every society. There is no doubt that socio-economic differences do not only determine an individual's level of mental development but also determines access to any level of educational attainment. Ehiametalor in Abdulkareem and Muraina (2014) revealed in his study that $70.2 \%$ of Nigerians are poor and went on to say that only $29.8 \%$ of families can live on one dollar (N380.00) or above a day. The socio-economic hardship experienced by the parents deprives many of access to university education. Only the children from the privileged class or high socio-economic background can afford the cost of private universities. This means the issue of access and equity is not addressed.

In the same vein, carrying capacity of universities is another major barrier to the equalization of educational opportunities. Due to the surging demand for university education, there was a need for universities to be expanded in terms of infrastructure, facilities and manpower to meet the teeming students' population seeking admission. As reported by Ngwuogu, Iloka, Ameh and DeekaMenegbon (2015), the National Universities Commission (NUC) at a time found out that many universities were overpopulated and facilities overstretched which informed the introduction of the carrying capacity to ensure that students are admitted based on the facilities available. This policy which was to ensure quality has become an impediment to the access and equalization of university education opportunity.

Inadequate number of staff could generate admission problem because the university is constrained to limit her admissions to tally with the academic staff strength. Efforts to increase enrolment and improve educational quality are severely constrained by growing shortages of qualified academic staff especially in Federal universities. According to Federal Ministry of Education (2009), the total number of academic staff in the Nigerian university system as at 2006 was 27,394, but about 50,000 (meaning a short fall of 19,548 academic staff) is required for effective course delivery across the disciplines.

Accreditation challenges also generate admission problem. If any of the universities could not meet the requirements and standard set by the regulatory body (Nigerian Universities Commission), they could be denied accreditation. Once accreditation is denied, such Universities or departments cannot admit until they meet up the requirements. This could reduce chances of admission to applicants that applied to such universities. Acute shortage of infrastructural 


\section{International Journal of Engineering Applied Sciences and Technology, 2019 \\ Vol. 4, Issue 3, ISSN No. 2455-2143, Pages 68-74 \\ Published Online July 2019 in IJEAST (http://www.ijeast.com)}

facilities like lecture halls, classrooms, hostels, laboratories, libraries and office accommodation affect students intake seriously. Most Universities lack these facilities and because of this, only few applicants are admitted. The universities can only admit numbers of candidates that hostels and lecture halls can accommodate (Ibrahim \& Ahmed, 2012).

The provision of equal access to educational opportunities for all citizens of the country at all levels of education changed the landscape of widening access to higher or tertiary education in Nigeria. The most significant policy initiatives taken by government that have increased access to tertiary education in Nigeria are the licensing of private tertiary institutions across the country, establishment of more federal universities and the reintroduction of the National Open University (by the former president of Nigeria, Chief Olusegun Obasanjo). The establishment of more universities by state governments is also complementing the effort of the Federal Government in this respect.

Saint, Haratnet and Streansnet (2003) further reported the inefficiency or lapses of the Joint Admission and Matriculation Board in a study they conducted on the effects of its methods of admission for higher education and found significant differences in academic performance between students admitted on merit and those admitted on the criteria. The dropout and repetition rates for the latter were three times greater than for the merit-based group.

Other hindrance that could affect the equalization of educational opportunities is the issue of funding. Government's effort in expanding university education is supposed to be accompanied with increased funding of the education sector. Unfortunately, budgetary allocation to the education sector over the years in Nigeria have consistently fallen short of United Nations Educational, Scientific and Cultural Organization (UNESCO) recommendation of $26 \%$ of annual budget allocation to education. For instance in 2012, 8.4\% was allocated to education, $8.7 \%$ in $2013,10.7 \%$ in 2014 , while $6.0 \%$ of the annual budget was allocated to education in 2016. Both the federal and state governments do not accord education the priority it deserves. Akuma in Ene (2007) pointed out that any government that places educational expenditures second or third in her budget list regards education as ill-investment and will reap the dividends in all direction. Poor funding led to many programmes in the universities being denied accreditation, led to the formulation of carrying capacity principle (which stipulated that admission of students should be based on available facilities) and led to inadequate provision of human and material resources. Thus, poor funding militates against government's effort in ensuring equality of educational opportunities.

The economic situation in the country has made it virtually impossible for many parents to have financial backing to sponsor their children or wards to undergo university education. The situation has made it so difficult that the cost of educating children is beyond the reach of many parents. Also, gender discrimination hinders equal opportunity to university education in Nigeria. By tradition or religion, preference is given to the education of male children by some families. The females are given out in early marriage. Ehiametalor (2005) in Omebe and Omebe (2014) reported that the number of females who took the 2004 university matriculation examination (UME) was 353,834 compared to 438,703 in 2003 ; this is a drop of $19.5 \%$. Socio economic factors influence the attainment of education.

Similarly, the result of this study is in agreement with Akpan and Amadi (2017) who asserted that even though there may seem to be autonomy and academic freedom, there are limits and boundaries set by the government. One of the reasons why the government may want to exercise maximum control may be due to its plan to use the university as machinery for the advancement of the state. Since the state needs a human resource, technological inventions and expertise skill to achieve its goals, the best way to regulate the entire process is to have the institutions under its whims and caprices. Based on the truism that 'who pays the piper dictates the tone', subsequent government keep insisting on influencing the appointment of Vice Chancellors, making regulations on students' enrolment mindless of what the university may consider appropriate or otherwise. In Nigeria, the National University Commission (NUC) has remained a very formidable agency of government that governs and regulates administrative and academic affairs of universities. The NUC retains the power to approve or disapprove academic programmes of universities. It, in fact, runs the universities from outside the campus. It is believed that NUC plays politics with the universities by luring the university management to its side and making them perceive the staff unions of the university such as the Academic Staff Union of the University (ASUU) as opposed to the management and government.

\section{CONCLUSION}

From the foregoing, this study has relatively shown that there are challenges facing equalization of 


\section{International Journal of Engineering Applied Sciences and Technology, 2019 \\ Vol. 4, Issue 3, ISSN No. 2455-2143, Pages 68-74 \\ Published Online July 2019 in IJEAST (http://www.ijeast.com)}

educational opportunities in universities in Nigeria. It is also clear that for a meaningful university education and for Nigerian universities to achieve the goals for which they have been established, it is imperative for them to enjoy the principles of autonomy in order to enhance equal educational opportunities for all. In this case, the universities should be allowed free hands to govern themselves. In that case, the curriculum of the institutions would be guarded and monitored by their respective Senates.

\section{RECOMMENDATIONS}

Based on the conclusion of the study, it was recommended that, the various organs of the university, such as Governing council, Senate, Faculties and Departments should be allowed to perform their statutory functions.

Autonomy should be granted to the universities in certain areas such as recruitment, training, and admission among others. There is the need to reposition the powers of some regulatory agencies of the university system such as the NUC, JAMB as well as government ministries to conform to the autonomy of universities as contained in the laws establishing universities in the country.

There is the need for the government to expand and improve the existing university facilities so as to be able to create more admission space for qualified candidates, increase the carrying capacities of universities and allow the universities to select their students.

\section{ACKNOWLEDGEMENT}

The authors specially thank the respondents for finding time from their busy schedules to respond objectively to the questionnaire items.

\section{REFERENCES}

1. Abdulkareem, A. Y. and Muraina, M. B. (2014). Issues and challenges of access and management of admission to universities in Nigeria. International Journal of Education and Research, Vol. 2, No. 6, pp 449-460.

2. Akpan, K. P. \& Amadi, G. (2017). University autonomy and academic freedom in Nigeria: A theoretical overview. International Journal of Academic Research and Development, Vol. 2, No. 4, pp 540-545.
3. Akpotu, N. E. (2005). Deregulating the Nigerian university system: Implications for equity and access. In G. O. Akpa, S. U. Udoh, and E. O. Fagbamiye (Eds), Deregulating the provision and management of education in Nigeria. Nigerian Association of Educational Administration and Planning (NAEAP), pp.5762.

4. Ene, A. C. (2007). Access to and equity in university education in Nigeria: Issues and trends. In J. B. Babalola, G. O. Akpa, A. O. Ayeni and S. O. Adedeji (Eds.), Access, equity and quality in higher education. NAEP publication. Pp 55-62.

5. Federal Ministry of Education (2009). Roadmap for the Nigerian education sector. Abuja: Author.

6. Federal Republic of Nigeria (2004). National Policy on Education. Lagos: NERDC.

7. Ibrahim, B. B. and Ahmed, U. M. (2012). Access to university education: Perceived problems militating against admission into Nigerian universities. Interdisciplinary Journal of Contemporary Research in Business, Vol. 4 No. 6, pp 244-254.

8. Musa, C. N. (2011). Equalizing educational opportunities in Nigeria in the $21^{\text {st }}$ century. Journal of Research in Education and Society, Vol. 2, No. 2, pp 21-30.

9. Ngwuogu, P. O., Iloka, C. R., Ameh, L. K. and Deeka-Menegbon, L. (2015). Politics of access and equity of educational opportunities in Nigeria. In N. M. Abraham, D. O. Durosaro, M. Nwadiani, G. G. Kpee, J. E. Okon and I. A. Odiba (Eds.), Politics of education and national development in Nigeria. Port Harcourt: University of Port Harcourt Press. Pp 603-610.

10. Njoku, U. M., Ifeditu, N. and Amadi, G. U. (2015). Equalization of educational opportunity in the $21^{\text {st }}$ century. In N. M. Abraham, D. O. Durosaro, M. Nwadiani, G. G. Kpee, J. E. Okon and I. A. Odiba (Eds.), Politics of education and national development in Nigeria. Port Harcourt: University of Port Harcourt Press. Pp 629-636.

11. Nwamuo, R. I., Okunamiri, M. C. and Okunamiri, P. O. (2015). The politics of access 
and equalization of educational opportunities: The Nigerian situation. In N. M. Abraham, D. O. Durosaro, M. Nwadiani, G. G. Kpee, J. E. Okon and I. A. Odiba (Eds.), Politics of education and national development in Nigeria. Port Harcourt: University of Port Harcourt Press. Pp 637-644.

12. Okorie, U. A. (2014). The right to higher education for national development and equal opportunity in Nigeria: The major challenges of our time. European Scientific Journal, Vol. 10, No. 10, pp 356-367.
13. Omebe, S. E. and Omebe, C. A. (2014). Impediments towards enlarging access to qualitative tertiary education in Nigeria. Journal of Education and Practice, Vol. 5, No. 30, pp 196-200.

14. Saint, W., Hartnett, T. and Strassner, E. (2003). Higher education in Nigeria: A status report. Higher Education Policy, 16, pp 259-281.

15. Ukertor, G. M. (2010). The challenges of access to university education in Nigeria. DSM Business Review, Vol. 2, No. 1, pp 35-39. 